\title{
Effect of Particle Size on Bamboo Particle Board Properties
}

\author{
Jessica Thais de Lira Bazzetto ${ }^{1}$ (D), Geraldo Bortoletto Junior ${ }^{1}$ (D), \\ Flavia Maria Silva Brito ${ }^{1}$
}

${ }^{1}$ Escola Superior de Agricultura "Luiz de Queiroz" - ESALQ, Universidade de São Paulo - USP, Piracicaba/SP, Brasil

\begin{abstract}
In this work, bamboo chips (Dendrocalamus asper) were crushed according to four particle size classes $(\mathrm{A}=-35+40$ mesh; $\mathrm{B}=-40+48$ mesh; $\mathrm{C}=-48+60$ mesh; $\mathrm{D}=-60+65$ mesh $)$ to produce particleboards with four different compositions $(100 \% \mathrm{~A} ; 75 \% \mathrm{~A}+25 \% \mathrm{~B} ; 50 \% \mathrm{~A}+50 \% \mathrm{~B}$; $25 \% \mathrm{~A}+25 \% \mathrm{~B}+25 \% \mathrm{C}+25 \% \mathrm{D})$. Each composition was considered a treatment. The aim was to verify the effect on the physical and mechanical properties of panels. The test methods and requirements to evaluate the properties were based on NBR 14810 Brazilian standard. The results showed that the particle size used in compositions showen no significant effect on moisture content, density, thickness swelling ( 24 hours), internal bonding or resistance to screw withdrawal (face and side) of panels. Significant effects were verified on water absorption (2 and 24 hours), thickness swelling (2 hours), MOR and MOE to static bending.
\end{abstract}

Keywords: panels, lignocellulosic composites. 


\section{INTRODUCTION}

Particleboards are products composed of wood particles bonded with synthetic adhesives that are consolidated under the action of heat and pressure, resulting in panels with variable final thickness between 3 and $50 \mathrm{~mm}$. Particleboards can be classified according to their density, adhesive nature, particle geometry, and other complementary features. Panels produced with density between 0.55 and $0.75 \mathrm{~g} / \mathrm{cm}^{3}$ are classified into the "medium density" category and are the most common (ABNT, 2013). According to Iwakiri (2005), these panels are widely used in the furniture industry and civil construction.

Several wood species and other lignocellulosic materials can be used for particleboard manufacture. Virtually any source of fiber can be used; however, the quality of the final product depends on the selection criterion (Roque \& Valença, 1998). Thus, studies on the quality of particleboard manufactured from alternative materials have intensified in Brazil, seeking to diversify the supply sources for industries whose main raw material is reforestation wood such as pine and eucalyptus.

One of these alternative materials is bamboo. According to Calegari et al. (2007), the interest in this material has increased worldwide because it is a perennial, renewable, fast growing resource of high productivity by area, low cost and diverse use, in addition to being considered an excellent carbon sequester. For Liese (1987) and Anokye et al. (2016), bamboo density ranges from 0.4 to $0.9 \mathrm{~g} / \mathrm{cm}^{3}$.

The most important variable of the raw material influencing the properties of panels is its density. The relationship between panel density and the density of the raw material used is known as compaction ratio. Low-density raw materials are preferred for producing medium density panels due to their adequate compaction ratio $(1,3)$, allowing sufficient contact area among particles during pressing, thus providing good bonding (Maloney, 1977).

According to Kelly (1977), medium-density panel produced with low-density raw materials will present higher compaction ratio and the resulting mechanical properties may be favored; however, the dimensional stability may be reduced compared to the same panel produced with higher-density raw materials.

Particle geometry (size and shape) affects the characteristics and properties of particleboards, as well as the type of raw material used, type and amount of adhesive and additives, and the panel structure, defined by the conditions in which the mattress is formed and the pressing conditions. Particle geometry intimately interacts with all these parameters, determining the particleboard properties (Maloney, 1977).

Strength to static bending, to parallel and perpendicular traction, and nail and screw withdrawal resistance are important properties of particleboards and are largely affected by particle geometry. Particle geometry also significantly affects the appearance of panel faces and corners. Small and thin particles provide panel smooth surfaces suitable for different types of coating due to their flexibility and ability to fill void spaces. Additionally, their flexibility greatly determines the degree of contact among particles, influencing particleboard strength (Moslemi, 1974).

Several studies on the experimental manufacture and particleboard quality using different bamboo species and wood particles, isolated or mixed, have been carried out; for example, those conducted by Vital \& Haselein (1988), Calegari et al. (2007), Arruda et al. (2011), Morais (2011), Melo et al. (2014, 2015), Valarelli et al. (2014), Morais et al. (2015), Nurhazwani et al. (2016). Among these studies, only that carried out by Nurhazwani et al. (2016) used Dendrocalumus asper bamboo, and none of them addressed the influence of particle size on panel properties.

On the other hand, other studies have investigated the influence of particle size on panel properties, although not using bamboo particles, such as those developed by Peixoto \& Brito (2000), Zheng et al. (2006), Osarenmwinda \& Nwachukwu (2007), Torrell et al. (2013), Lias et al. (2014) and Farrokhpayam et al. (2016).

Thus, the aim of the present study was to evaluate the effect of particle size on the physical and mechanical properties of bamboo particleboards (Dendrocalamus asper) produced at laboratory scale.

\section{MATERIAL AND METHODS}

\subsection{Bamboo collection and particle collection}

Bamboo (Dendrocalamus asper) used in the present study was collected at the Research and Development Unit (UPD) of the Agronomic Institute of Campinas (IAC), located in the city of Tatuí/SP. Stems from 
bamboo plants aged between three and four years were cut with the aid of a chainsaw. Culms of $2.00 \mathrm{~m}$ in length were obtained by sectioning the cut stem. The material collected in the field was subsequently transported to the laboratory to be processed.

Culms were cut lengthwise to obtain slats using a circular saw. Slats were subsequently processed into a planer to remove internal (starch-rich) and external (bark) layers. Finally, slats were turned into chips using a band saw. Bamboo chips samples were selected to determine the basic density, which was tested according to NBR 11941 standard procedures (ABNT, 2003). Chips were then dried in the open air until reaching $15-18 \%$ moisture, and then converted into particles using Wiley mill.

The particles obtained were classified using a vibrating machine and sieves of 35 mesh $(0.500 \mathrm{~mm})$, 40 mesh $(0.420 \mathrm{~mm}), 48$ mesh $(0.297 \mathrm{~mm}), 60$ mesh $(0.250 \mathrm{~mm})$ and 65 mesh $(0.210 \mathrm{~mm})$. Particles of 04 granulometric classes were used for producing particleboards: $-35+40$ mesh; $-40+48$ mesh; $-48+60$ mesh; $-60+65$ mesh. Symbols (-) and (+) indicate passage and retention of particles, respectively. The gradual inclusion of smaller size particles in the produced panels (see Table 1) was to improve their surface characteristics.

\subsection{Experimental design and data analysis}

The experimental design adopted for the manufacturing of panels was completely randomized, consisting of four treatments as described in Table 1. Three replicates were adopted for each treatment, totaling 12 experimental panels produced.

Analysis of variance was performed, followed by the Tukey test for comparison of means at 5\% level of error probability to verify the effect of treatments on the properties of bamboo particleboard panels, as described in item 2.4 .

\subsection{Bamboo particleboard manufacturing}

According to the experimental design adopted, homogeneous panels (single layer) were manufactured with nominal density and thickness of $0.65 \mathrm{~g} / \mathrm{cm}^{3}$ and $15.7 \mathrm{~mm}$, respectively.

The nominal density adopted for the manufacturing of panels was stipulated based on the range from 0.55 to $0.75 \mathrm{~g} / \mathrm{cm}^{3}$ determined by NBR 14810 standard (ABNT, 2013) for panels of medium density particles. Density and nominal thickness values were adopted for the experiment because they are very common for commercial panels, especially those used in the furniture sector.

Urea-formaldehyde (UF) resin was applied at content of $10 \%$ resin solids, based on particle mass at $0 \%$ moisture. Ammonium sulfate solution at proportion of $5 \%$ solids was incorporated into the adhesive.

Previously prepared adhesive and catalyst were mixed and applied to dried particles (3\% to 5\% moisture) inside a rotary drum type gluer through compressed air gun. Paraffin emulsion at level of $1 \%$ solids was subsequently applied using the same equipment as for the adhesive, only replacing the air gun.

Particle mass impregnated with adhesive and paraffin was manually deposited into a wooden box with internal dimensions of $40 \mathrm{~cm} \mathrm{x} 40 \mathrm{~cm}$ to form the mattress. Subsequently, the mattress was cold pre-pressed in a manual hydraulic press for air removal and pre-consolidation. The mattress was then hot-pressed in a motorized hydraulic press with automatic control of temperature, pressure, and closing and opening time of plates. The pressing cycle parameters were the following: $35 \mathrm{kgf} / \mathrm{cm}^{2}$ of pressure, temperature of $180^{\circ} \mathrm{C}$ and total time of 10 minutes (01 minute for closing and reaching the maximum pressure, 08 minutes under maximum pressure and 01 minute for opening).

Table 1. Experimental design.

\begin{tabular}{ccccc}
\multirow{2}{*}{ Treatments } & \multicolumn{4}{c}{ Particle size used in panel manufacturing } \\
(Mesh)
\end{tabular}




\subsection{Obtaining specimens and evaluation of panel properties}

Upon reaching constant mass, panels were trimmed using a circular saw, removing $10 \mathrm{~mm}$ from each of its sides. Then, specimens were prepared for the determination of the following physical and mechanical properties: moisture content, density, absorption and swelling after 2 and 24 hours of immersion in water, modulus of rupture (MOR) and modulus of elasticity (MOE) to static bending, resistance to screw withdrawal (face and side) and internal bonding. Specimen dimensions and tests followed requirements of NBR 14810 standard (ABNT, 2013).

\section{RESULTS AND DISCUSSION}

\subsection{Basic density of bamboo chips}

The basic density of bamboo chips was $0.53 \mathrm{~g} / \mathrm{cm}^{3}$. This value is included in the range from $0.40 \mathrm{~g} / \mathrm{cm}^{3}$ to $0.90 \mathrm{~g} / \mathrm{cm}^{3}$ as indicated by Liese (1987) and Anokye et al. (2016) for different bamboo species.

\subsection{Physical properties of bamboo particleboard}

\subsubsection{Moisture content, density and compaction ratio}

Moisture content, density and compaction ratio values of panels for each treatment are shown in Table 2 .

According to the analysis of variance performed for the moisture content and density of panels, no significant differences among treatments were found. Thus, particle size had no influence on none of these variables.

According to NBR 14810 standard (ABNT, 2013), the moisture content of particleboard panels ranged from 5 to 13\%. It was observed that all mean values presented in Table 2 are within the moisture range.

Table 2 shows that panels from all treatments were within the "medium density" category, as defined by NBR 14810 standard (ABNT, 2013). However, the mean density values of panels were below the experimentally planned nominal value $\left(0.65 \mathrm{~g} / \mathrm{cm}^{3}\right)$. This fact is not uncommon and may be associated with loss of adhesive and paraffin during application and material loss during the manual formation of the particle mattress, as well as during the pre-pressing and hot pressing steps. Melo et al. (2015) also reported this fact and attributed factors such as loss of adhesive and paraffin at the application time due to adhesion on the edges of the drum and differences in the specific mass and moisture content of particles.

The effective compaction ratio of panels practically did not vary (1.09 to 1.11; Table 2), remaining below the value considered ideal $(\geq 1.3)$ as suggested by Maloney (1977).

\subsubsection{Water absorption and thickness swelling}

Water absorption and thickness swelling values of panels for each treatment are shown in Table 3.

The analysis of variance performed for the absorption and swelling of panels revealed that there were significant differences among treatments for both variables, except in the case of TS after 24 hours. Thus, it was verified that particle size distribution influenced both variables in all cases, except for TS after 24 hours.

It was observed that there was a tendency to increase the mean WA value (at 2 and 24 hours) as the proportion of smaller-size particles increased in panels; this fact was very evident when comparing the average values obtained for panels of $\mathrm{T} 1$ and $\mathrm{T} 4$ treatments. By increasing the proportion of smaller-size particles, the surface area and particle volume also increase,

Table 2. Mean moisture content, density and compaction ratio values of panels.

\begin{tabular}{cccc} 
Treatments & $\begin{array}{c}\text { MC } \\
(\%)\end{array}$ & $\begin{array}{c}\text { Density } \\
\left(\mathbf{g} / \mathbf{c m}^{3}\right)\end{array}$ & CR \\
\hline T1 & $10.9 \mathrm{a}$ & $0.59 \mathrm{a}$ & 1.11 \\
T2 & $11.0 \mathrm{a}$ & $0.58 \mathrm{a}$ & 1.09 \\
$\mathrm{~T} 3$ & $10.7 \mathrm{a}$ & $0.58 \mathrm{a}$ & 1.09 \\
$\mathrm{~T} 4$ & $10.7 \mathrm{a}$ & $0.59 \mathrm{a}$ & 1.11 \\
\hline
\end{tabular}

Means followed by the same letter in column do not differ statistically by the Tukey test $(\alpha=0.05)$. MC: Moisture Content; CR: Compaction Ratio. 
Table 3. Mean water absorption and thickness swelling values of panels.

\begin{tabular}{cccccc}
\multirow{2}{*}{ Treatments } & \multicolumn{3}{c}{ WA (\%) } & & \multicolumn{2}{c}{ TS (\%) } \\
\cline { 2 - 3 } \cline { 5 - 6 } & 2 hours & $\mathbf{2 4}$ hours & & 2 hours & 24 hours \\
T1 & $34.4 \mathrm{c}$ & $42.2 \mathrm{~b}$ & & $6.7 \mathrm{~b}$ & $9.3 \mathrm{a}$ \\
T2 & $36.2 \mathrm{bc}$ & $43.7 \mathrm{ab}$ & & $6.7 \mathrm{~b}$ & $8.9 \mathrm{a}$ \\
T3 & $38.9 \mathrm{ab}$ & $44.1 \mathrm{ab}$ & & $7.0 \mathrm{ab}$ & $8.9 \mathrm{a}$ \\
T4 & $42.1 \mathrm{a}$ & $45.4 \mathrm{a}$ & & $8.0 \mathrm{a}$ & $9.4 \mathrm{a}$ \\
\hline
\end{tabular}

Means followed by the same letter in column do not differ statistically by the Tukey test $(\alpha=0.05)$. WA: Water Absorption; TS: Thickness Swelling.

causing more empty spaces to be occupied by the absorbed water, especially in the cell lumen, which could be a possible explanation for the results obtained.

Part of the swelling occurs when water starts to occupy the absorption sites. It could be assumed that the adhesive content, especially the applied paraffin content, may not have been sufficient to cover the larger particle surface area of T4 treatment panels; therefore, not forming a barrier to water entry into cell walls in the same magnitude as larger-size particles (T1) due to their possible greater coating capacity. However, in accordance with Moslemi (1974), paraffin is effective during short immersion periods. After long immersion period, the paraffin loses efficiency and this may explain the swelling increase from 2 to 24 hours, as well as the statistical equality of means for TS panel after 24 hours for all treatments.

In determining the requirements for non-structural panels for internal use in dry conditions (P2Type) in the thickness range from $13 \mathrm{~mm}$ to $20 \mathrm{~mm}$, the NBR 14810 standard (ABNT, 2013) does not establish maximum WA values ( 2 and 24 hours) or TS values after 2 hours; however, in the case of TS after 24 hours, the maximum percentage allowed by the standard is $18 \%$. Table 3 shows that the panels of all treatments met this requirement. Part of the swelling is due to the release of pressing tensions, both increasing as the compaction ratio increased. Considering that the compaction ratio of panels practically did not vary and was low (Table 2), this may explain why TS values were also low.

Nurhazwani et al. (2016) produced homogeneous single-layer particleboards using bamboo particles (Dendrocalamus asper) and rubber tree (Hevea brasiliensis) particles, both from a single granulometric class $(-10+35$ mesh), isolated and mixed at different proportions. Particles were glued using urea-formaldehyde-based adhesive at $12 \%$ content and panels were produced with nominal density and thickness of $0.70 \mathrm{~g} / \mathrm{cm}^{3}$ and $12 \mathrm{~mm}$, respectively, without the addition of paraffin. The physical and mechanical properties of panels were determined for particleboards produced with $100 \%$ bamboo particles and the authors found WA and TS values after 24 hours of $68.8 \%$ and $20.1 \%$, respectively, which in both cases are higher than those found in the present study (Table 3). The authors considered that the values found were unsatisfactory, which could be due to the non-inclusion of paraffin.

In determining the properties of particleboards (12 $\mathrm{mm}$ in thickness) produced with particles of $2.00 \mathrm{~mm}$ and $1.00 \mathrm{~mm}$, Lias et al. (2014) found increase in WA values and reduction in TS values with the decrease in particle size. The same tendency was found by Farrokhpayam et al. (2016) when evaluating the properties of particleboards (3.7 $\mathrm{mm}$ in thickness) produced with particles from class $-8+12$ mesh $(2.38 \mathrm{~mm}$ to $1.68 \mathrm{~mm})$ and class $-18+25$ mesh (1.00 $\mathrm{mm}$ to $0.707 \mathrm{~mm}$ ).

\subsection{Mechanical properties of bamboo particleboard panels}

The modulus of rupture (MOR), modulus of elasticity (MOE), internal bonding and screw withdrawal resistance (face and side) values of panels for all treatments are shown in Table 4.

\subsubsection{Modulus of rupture and modulus of elasticity to static bending}

The analyses of variance performed for MOR and MOE of panels revealed significant differences among treatments in both cases, demonstrating that the particle size distribution influenced both variables.

By analyzing data in Table 4, it was possible to observe that as the proportion of smaller-size particles 
Table 4. Mean MOR, MOE, internal bonding and screw withdrawal resistance values of panels.

\begin{tabular}{|c|c|c|c|c|c|}
\hline \multirow[t]{2}{*}{ Treatments } & \multicolumn{2}{|c|}{$\begin{array}{c}\text { SB } \\
(\mathrm{MPa})\end{array}$} & \multirow{2}{*}{$\begin{array}{c}\text { IB } \\
(\mathrm{MPa})\end{array}$} & \multicolumn{2}{|c|}{$\begin{array}{c}\text { SWR } \\
(\mathbf{N})\end{array}$} \\
\hline & MOR & MOE & & Face & Side \\
\hline $\mathrm{T} 1$ & $7.6 \mathrm{a}$ & $981 \mathrm{a}$ & $0.25 \mathrm{a}$ & $706 a$ & $572 \mathrm{a}$ \\
\hline $\mathrm{T} 2$ & $7.2 \mathrm{a}$ & $927 \mathrm{ab}$ & $0.27 \mathrm{a}$ & $673 \mathrm{a}$ & $559 a$ \\
\hline T3 & $6.0 \mathrm{ab}$ & $774 \mathrm{bc}$ & $0.28 \mathrm{a}$ & $609 a$ & $524 \mathrm{a}$ \\
\hline $\mathrm{T} 4$ & $5.2 \mathrm{~b}$ & $693 c$ & $0.26 \mathrm{a}$ & 599 a & $464 \mathrm{a}$ \\
\hline
\end{tabular}

Means followed by the same letter in column do not differ statistically by the Tukey test ( $\alpha=0.05)$. SB: Static Bending; MOR: Modulus of Rupture; MOE: Modulus of Elasticity; IB: Internal Bonding; SWR: Screw Withdrawal Resistance.

increased in panels, there was a tendency for the mean MOR and MOE values to decrease. It is assumed that the adhesive content applied was not enough to cover the larger surface area of smaller-size particles, and therefore the increase in the contact area among particles did not result in sufficient number of adhesive bonds.

When stipulating the requirements for Type-2 panels with thickness ranging from $13 \mathrm{~mm}$ to $20 \mathrm{~mm}$, the NBR 14810 standard (ABNT, 2013) determines minimum MOR and MOE values of $11 \mathrm{MPa}$ and $1600 \mathrm{MPa}$, respectively. Data in Table 4 show that none of the panels for treatments satisfied MOR and MOE values required by this standard. In addition to the insufficient amount of adhesive, the low compaction ratio of panels may also have contributed to these results (Table 2).

Nurhazwani et al. (2016) found values of 15.3 MPa for MOR and $2650 \mathrm{MPa}$ for MOE in particleboards manufactured with $100 \%$ bamboo particles (D. asper); both values were higher than those found in the present study (Table 4). Without disregarding other possible factors, the density of panels, the adhesive content applied and the particle size may have contributed to such superiority, as the values found by these authors were higher.

Lias et al. (2014) and Farrokhpayam et al. (2016) found reduction in MOR and MOE values to static bending for panels with decreased particle size.

\subsubsection{Internal bonding}

The analysis of variance performed for the internal bonding of panels showed no significant differences among treatments. Therefore, particle size distribution had no influence on this property.

The NBR 14810 standard (ABNT, 2013) stipulates minimum value of $0.35 \mathrm{MPa}$ for IB (perpendicular tensile strength) for Type 2 panels, with thickness ranging from $13 \mathrm{~mm}$ to $20 \mathrm{~mm}$. According to data shown Table 4, it could be observed that none of panels for treatments met the requirements established by this standard.

The low IB values obtained for panels for all treatments evidenced the hypothesis that the adhesive content applied was insufficient, considering that this property reveals the degree of adhesive bonding among particles. In addition, the low compaction ratio value of panels may have contributed to these results.

Nurhazwani et al. (2016) found IB value of $0.58 \mathrm{MPa}$ in particleboards manufactured with $100 \%$ bamboo particles (D. asper). This result was higher than values found in the present study (Table 4).

Lias et al. (2014) observed an increase in the IB value of panels with the decrease in particle size. In contrast, Farrokhpayam et al. (2016) found the opposite.

\subsubsection{Screw withdrawal resistance}

The analysis of variance performed for screw withdrawal resistance on face and side of panels revealed no significant differences among treatments for both variables. Thus, particle size distribution had no influence on these properties.

Although not statistically significant, Table 4 shows that there was a tendency for SWR values (face and side) to decrease as the proportion of smaller-size particles in panels increased. This observation is consistent with the findings by Maloney (1993), who reported that this property is directly related to the size of particles used in panel manufacture.

It was observed that the SWR values of face were higher than those of side for all treatments. This result is due to the fact that in the first case, the screw goes throughout the panel thickness, and in the second, the screw is only inserted in the central layer, the 
region in which the panel density is lower in relation to the density of faces, thus offering less resistance to its removal.

NBR 14810 (ABNT, 2013), which became effective at the beginning of 2014, does not determine minimum SWR values. The standard considers that it is a supplementary property, specific for certain applications, thus suggesting that the manufacturer should provide this type of information if required.

Former NBR 14810 standard (ABNT, 2006), which was in force until the end of 2013, stipulated minimum SWR values equal to $1,020 \mathrm{~N}$ (face) and $800 \mathrm{~N}$ (side) for Type 2 panels with thickness ranging from $14 \mathrm{~mm}$ to $20 \mathrm{~mm}$. Only as a reference, data in Table 4 show that panels from all treatments would not meet requirements of the former standard, considering both properties evaluated. In fact, the SWR values (face and side) of all panels were low. Thus, these results (in addition to particle size distribution) may be related to insufficient adhesive content and low compaction ratio.

Nurhazwani et al. (2016) found SWR (face) values corresponding to $499.9 \mathrm{~N}$ for $100 \%$ bamboo particleboards (D. asper), which were lower than results found in the present study (Table 4).

\section{CONCLUSIONS}

The size of particles used in panel manufacturing had no significant effect on moisture content, density, thickness swelling (TS) after 24 hours, internal bonding (IB) and screw withdraw resistance (SWR) of face and side;

Significant effect was observed on water absorption (WA) at 2 and 24 hours, TS at 2 hours, MOR and MOE to static bending;

WA values at 2 and 24 hours showed tendency to increase with increase in the proportion of smaller-size particles in the composition; however, the opposite was verified for MOR and MOE values. The same trend observed for MOR and MOE values was observed for the SWR properties, although not significant;

Among properties evaluated, only the TS after 24 hours met requirements of the Standard used as reference;

Increasing the adhesive content applied and increasing the nominal density of panels in order to achieve higher compaction ratio are measures that could be considered to improve the performance of panels obtained in the present study.

\section{SUBMISSION STATUS}

Received: 13 feb., 2017

Accepted: 19 jan., 2018

\section{CORRESPONDENCE TO}

\section{Geraldo Bortoletto Junior}

Escola Superior de Agricultura "Luiz de Queiroz" - ESALQ, Universidade de São Paulo - USP, Av. Pádua Dias, 11, CEP 13418-900, Piracicaba, SP, Brasil

e-mail: gbjunior@usp.br

\section{REFERENCES}

Anokye R, Bakar ES, Ratnansingam J, Awang KB. Bamboo properties and suitability as a replacement for wood. Pertanika Journal of Scholarly Research Reviews 2016; 2(1), 63-79.

Arruda LM, Del Menezzi CHS, Teixeira DE, Araújo PC. Lignocellulosic composites from Brazilian giant bamboo (Guadua magna) Part 1: Properties of resin bonded particleboards. Maderas. Ciencia y Tecnología 2011; 13(1): 49-58. http://dx.doi.org/10.4067/S0718221X2011000100005.

Associação Brasileira de Normas Técnicas - ABNT. NBR 11941: Determinação da densidade básica. Rio de Janeiro: ABNT; 2003.

Associação Brasileira de Normas Técnicas - ABNT. NBR 14810: Chapas de madeira aglomerada. Parte 2: Requisitos. Rio de Janeiro: ABNT; 2006.

Associação Brasileira de Normas Técnicas - ABNT. NBR 14810: Chapas de madeira aglomerada. Parte 2: Requisitos e métodos de ensaio. Rio de Janeiro: ABNT; 2013.

Calegari L, Haselein CR, Scaravalli TL, Santini EJ, Stangerlin DM, Gatto DA et al. Desempenho físico-mecânico de painéis fabricados com bambu (Bambusa vulgaris Schr.) em combinação com madeira. Cerne 2007; 13(1): 57-63.

Farrokhpayam SR, Valadbeygi T, Sanei E. Thin particleboard quality: effect of particle size on the properties of the panel. Journal of Indian Academy of Wood Science 2016; 13(1): 38-43. http://dx.doi.org/10.1007/s13196-016-0163-9.

Iwakiri S. Painéis de madeira reconstituída. Curitiba: FUPEF; 2005. 254 p.

Kelly MW. Critical literature review of relationships between processing parameters and physical properties of 
particleboards. Madison: USDA Forest Service, Forest Products Laboratory; 1977. 65 p. General Technical Report FPL-10.

Lias H, Kasin J, Johari NAN, Moktar ILM. Influence of board density and particle sizes on the homogeneous particleboard properties from kelempayan (Neolamarckia cadamba). International Journal of Latest Research in Science and Technology 2014; 3(6): 173-176.

Liese W. Research on bamboo. Wood Science and Technology 1987; 21: 189-209.

Maloney TM. Modern particleboard \& dry-process fiberboard manufacturing. Sao Francisco: Miller Freeman Publication; 1977. 672 p.

Maloney TM. Modern particleboard \& dry-process fiberboard manufacturing. Sao Francisco: Miller Freeman Publication; 1993. $681 \mathrm{p}$.

Melo RR, Stangerlin DM, Santana RRC, Pedrosa TD. Physical and mechanical properties of particleboard manufactured from wood, bamboo and rice husk. Materials Research 2014; 17(3): 682-686. http://dx.doi.org/10.1590/ S1516-14392014005000052.

Melo RR, Stangerlin DM, Sousa AP, Cademartori PHG, Schneid E. Propriedades físico-mecânicas de painéis aglomerados madeira-bambu. Ciência Rural 2015; 45(1): 35-42. http://dx.doi.org/10.1590/0103-8478cr20120970.

Morais WWC, Haselein CR, Susin F, Vivian MA, Morais JBF. Propriedades físico-mecânicas de painéis aglomerados com Bambusa tuldoides e Pinus taeda. Ciência Florestal 2015; 25(4): 1015-1026. http://dx.doi. org/10.5902/1980509820662.

Morais WWC. Propriedades físico-mecânicas de chapas aglomeradas produzidas com bambu, pinus e eucalipto. [dissertação]. Santa Maria: Centro de Ciências Rurais, Universidade Federal de Santa Maria; 2011.

Moslemi, A. A. Particleboard. Vol. 1. London: Southern Illinois University Press; 1974. 244 p.
Nurhazwani O, Jawaid M, Paridah MT, Abdul JH, Hamid SA. Hybrid particleboard from bamboo (Dendrocalamus asper) veneer waste and rubberwood (Hevea brasiliensis). BioResources 2016; 11(1): 306-323.

Osarenmwinda JO, Nwachukwu JC. Effect of particle size on some properties of rice husk particleboard. Advanced Materials Research 2007; 18-19: 43-48. http://dx.doi. org/10.4028/www.scientific.net/AMR.18-19.43.

Peixoto GL, Brito EO. Avaliação da granulometria de partículas de Pinus taeda combinadas com adesivos comerciais para a fabricação de aglomerados. Floresta e Ambiente 2000; 7(1): 60-67.

Roque CAL, Valença ACV. Painéis de madeira aglomerada. No. 8. Rio de Janeiro: BNDES Setorial; 1998. p. 153-170.

Torrell R, Hillig E, Corradi GM, Iwakiri S. Influência da adição de serragem nas propriedades tecnológicas de painéis de madeira aglomerada de Pinus taeda. Ambiência 2013; 9(1): 57-72. http://dx.doi.org/10.5777/ ambiencia.2013.01.04.

Valarelli IDD, Battistelle RAG, Bueno MAP, Bezerra BS, Campos CI, Alves MCS. Physical and mechanical properties of particleboard bamboo waste bonded with urea formaldehyde and castor oil based adhesive. Matéria (Rio de Janeiro) 2014; 19(1): 1-6. http://dx.doi.org/10.1590/ S1517-70762014000100002.

Vital BR, Haselein CR. Qualidade de chapas de aglomerado produzidas com embaúba (Cecropia sp) e bambu (Bambusa vulgaris). Árvore 1988; 12(2): 134-145.

Zheng Y, Pan Z, Zhang R, Jenkins BM, Blunk S. Properties of medium-density particleboard from saline Athel wood. Industrial Crops and Products 2006; 23(3): 318-326. http:// dx.doi.org/10.1016/j.indcrop.2005.09.003. 